\title{
Information Needs of Sesame Farming Households in Selected Agricultural Zones of Katsina State, Nigeria
}

\author{
Ikwuakam, 0. T1 \\ lyela, $\mathrm{A}^{2}$ \\ Sangotegbe, N. S $^{3}$ \\ ${ }^{1}$ Federal College of Education, Katsina. PMB 2041; ikwuosca@yahoo.com \\ 2Federal College of Education, Okene, PMB 1026 \\ 3University of Ibadan, Ibadan; siji004u@yahoo.com
}

\section{Doi:10.5901/mjss.2016.v7n1s1p204}

\section{Abstract}

\begin{abstract}
The study examined information needs of sesame farming households in selected agricultural zones of Katsina state, Nigeria. A multistage sampling procedure was used in selecting 170 sesame farmers across Katsina state. Data were obtained with the aid of a well-structured interview schedule, and analyzed using percentages, mean, chi-square and PPMC. Results revealed that average age, household size and farm size were $39 \pm 11.5,9.11 \pm 5.7$ and $2.00 \pm 1.78$ respectively. Majority were males (95.0\%), married (89.3\%) and had Quranic education (64.3\%). Sesame farmers got information through personal experience $(\bar{x}=2.65)$, radio/television $(\bar{x}=2.12)$ as well as friends and neighbour $(\bar{x}=2.09)$. The most important information needs of respondents were on improved seed varieties $(\bar{x}=2.77)$, fertilizer and manure application $(\bar{x}=2.75)$, better storage strategies $(\bar{x}=2.68)$ and agricultural insurance $(\bar{x}=2.67)$. The following constraints to accessing information on sesame production were identified, including inadequate extension contact $(\bar{x}=1.92)$, poor communication network $(\bar{x}=1.87$ ) and lack of agriculturalbased television programmes $(\bar{x}=1.68)$. Farm size $(r=-0.178, p=0.036)$ had significant relationship with respondents' information needs. There is the need for extension programme to be revitalized in Katsina State with the aim of addressing the common needs of farmers on economically important crops such as sesame.
\end{abstract}

Keywords: Information needs, sesame, farmers, constraints

\section{Introduction}

Sesame or benniseed is a tropical annual plant that is remarkably produced for its seeds and oil. Purseglove, (1996) reported that its original area of domestication is tropical Africa, where greatest genetic diversity exists and from where it spread to India a port of sesame secondary diversity development. Other names of sesame as captured by Abu, Ater and Abah (2012) include: "simsim" in East Africa, "Till" in India and "Gingely" in Sri-Lanka, "Ridi", "Ekuku" and "Isasa" in Hausa, Ibo and Yoruba tribes of Nigeria respectively.

Sesame production at world level is estimated at 3.15 million tonnes per year having risen from 1.4 million tonnes in the early 1960s with Asia and Africa producing 70 and $26 \%$ of this estimation respectively (FAO, 2009). In Nigeria, sesame is becoming an important component of Nigeria's agricultural exports given its current rate of cultivation. Today, both the white and brown types are commonly grown by smallholder farmers in Nasarawa, Jigawa and Benue States (Raw Materials Research Development Council (RMRD) 2004). Others are Yobe, Kano, Katsina, Kogi, Gombe and Plateau States.

At global level, exports in year 2000 were put at 657,000 tonnes having risen from 427,000 tonnes in 1988 (USAID 2002). The same report valued the 2000 exports at $\$ 478 \mathrm{mn}$ with India recording the single largest exporter with 180,000 tonnes seconded by Sudan's over 138,000 tonnes export per year. Nigeria similarly, enjoys a rising profile on the world market. USAID (2002) and OIAM (2005) valued annual exports from Nigeria at about US\$20 million with Japan dominating the purchasing side of the trade. This may be attributed to the growing importance of sesame oil, especially as a crucial component of Japanese cooking as well as increased consumer concern for healthy eating.

In addition to sesame's economic value, Burden, (2005) found out that beniseed is one of the world's oldest spice and oil seed crops grown for its seeds that contain approximately 50\% oil, $25 \%$ protein and antioxidants (Sesamun, Sesamolin and Sesamol); a quality Umar (2010) noted makes the oil one of the most stable vegetable oils in the world. 
In Nigeria, the crop has remained a popular cash crop among farmers due to its good local and international markets potentials. This made Nasarawa State Government to identify sesame as a major revenue earner and consequently established a sesame seeds cleaning plant (Nasarawa State Government, 2008). Also, in 2007 a pilot project to increase sesame production and utilization for economic empowerment in the northern states of Nigeria was jointly undertaken by the National Sesame Seeds Association and the First Bank of Nigeria (Abdullah 2009). Thus, Mshelia, Sajo and Gungula (2012) revealed that sesame seeds farming can provide one million jobs and earn US\$1.5 billion for the northern states of Nigeria thereby empowering the people of the region economically. This undoubtedly has implication on rural employment generation and development, enhancing rural income and socio-economic well being of farming households. Nigeria was also noted to have earned US $\$ 798,049,000$ (Mshelia, et.al 2012). The seeds are also demanded in various forms; raw seeds, crushed unrefined and refined oil. This is in addition to its total annual consumption which Mshelia, et.al (2012) put at about $65 \%$ for oil extraction and $35 \%$ for food.

It is important therefore to state that provision of right type of information that revolves around modern agricultural technology, credit, erosion control, soil fertility, improved seeds varieties and seedlings, plant protection chemicals, water, markets, machinery and equipment are germane if the levels of growth and benefits in sesame production are to be improved and sustained. Mshelia, et.al (2012) observed that Nigerian farmers are yet to take adequate advantage of the robust market potential sesame commands to improve their economy. Olam (2005) attributed this to the growing gap between demand information and supply of sesame. Also Aina (2004) observed that poor access to information and training has remained the bane of most farm families. Ajayi, Banmeke and Solomon (2010) reiterated that even when farmers are exposed to information, cursory observation has revealed that most disseminated information are usually given without needs assessment and identification and this has implication for capacity building.

This implies that the popular saying that "for lack of knowledge the chicken slept hungry right on top of a bag of grain", is what is happening with our farming households as they cannot make fortune from sesame farming. Information is a basic element in any development activity and useful when appropriately made available and accessible (Judamat, Adekoya \& Abu 2010). In agriculture, the role of information in enhancing development is obvious. Adedoyin (1990) posited that a steady flow of accurate, understandable and factual information links scientist with farmers, in which for any true agricultural progress, farmers must know, understand, and act on. Suffice this to mean that how far people progress in whatever they do depends upon the availability and access to accurate and reliable information (Ajayi et al 2010). Therefore, identifying the information needs of sesame farming households could help research activities at solving farming households' problems and ensures that those involved in extension services design and disseminate appropriate information to them. This will build competency, improve yield, profit, and improve living standard and sustainable production among sesame farming households. This study therefore aimed at determining information needs of sesame farming households in selected agricultural zones of Katsina State, Nigeria. The specific objectives include:

1. Determine the socio-economic characteristics of the respondents

2. Identify respondents' sources of information

3. Ascertain information needs of the respondents

4. Identify constraints to respondents' access to information

\section{Hypothesis}

1. There is no significant relationship between the socio-economic characteristics of the respondents and their level of information needs

\section{Literature Review}

Sesame is a rich oil seed crop with great socio-economic potentials particularly in tropical Africa from where Abu, Ater and Abu (2012) reported it originated and taken to India (Purseglove, 1996). Its cultivation was originally at subsistence level and purpose but has over the years grown to become an important commercially cultivated oil seed crop globally. Sesame's remarkable uniqueness in thriving and yielding well even in poor soil and climatic conditions may be part of the reasons for its wide spread cultivation among farmers in Africa, Europe and Asia.

Chemonics (2003) revealed that the plant has short harvest cycle of $90-140$ days, measuring 60 to $120 \mathrm{~cm}$ tall, whitish to brown or black seeds depending on the variety with a high oil content of $44-60 \%$, deep rooting and well adapted to withstand dry conditions, poor soils and climates that are generally unsuitable for other crops. This same source maintained that sesame thrives around the dry tropics between the latitudes of $40^{\circ} \mathrm{N}$ and S.

Today, evidence has shown that the world crop area under sesame is about 6 million hectares (Abu et.al 2012). 
FIIR (1990) in Abu et.al (2012) also reported that $65 \%$ and $25 \%$ of this estimate is cultivated in Asia and Africa respectively while $8 \%$ was from America, Venezuala, Mexico, Gautamala, Columbia and Sudan. Anon, (2008) had also corroborated that of the 3.66 million tons world estimated sesame production, Asia and Africa produce 2.55 and 0.95 million tons respectively. Although, Sudan, Ethiopia, Keya, Egypt, Mali, Burkina Faso, Tanzania and Chad are among the major players in sesame cultivation in Africa; Nigeria is reportedly the $2^{\text {nd }}$ largest producer in Africa $(F A O, 2008)$ and $7^{\text {th }}$ in the world with estimated production figure of 120,000 metric tons annually (Abu et.al 2012) on a cultivated area of over 80,000 ha across the Northern States (Umar, Okoye and Mamman 2010). Raw Materials Research and Development Council, (RMRDC) (2004) in Umar et.al (2010) noted that Benue and Nasarawa States rank highest with an annual production of not less than 40,000 metric tons. China and India are the world largest producers each with an annual harvest of about 750,000 tons followed by Myanmar (425,000 tons) and Sudan (300,000 tons) (Chemonics 2003).

The increasing rise in sesame production across the world is undoubtedly due to its robust socio-economic values and demand. FAO, (2000) observed that Nigeria earned an estimated US\$20 million from sesame export. FAO (2009) had earlier buttressed that the country's estimated volume of sesame export also hit 150,000 tons in 2008. (Oluwe et. al (2009) noted that sesame is enjoying high market rate due to its potential in meeting health requirements for food. Mshelia et.al (2012) corroborated that Sesame is rich in natural oil soluble and water soluble anti-oxidants such as sesamin, sesamolin, sesamonial and sesaminol glucosides. This could be a reason why it is called "Queen of oils or king of oils" (Random Nature 2009). Thus, about $65 \%$ of the annual production of sesame is reportedly processed into oil while 35\% used as food (Mshelia et.al (2012) while about $42 \%$ is roasted sesame, $36 \%$ washed sesame, $12 \%$ ground sesame and $10 \%$ sesame roasted seeds with salt (Random Nature, 2009). Falusi, (2008) found out that the oil rich crop can be roasted and sprinkled on pan-cakes, chinchin and donuts as well as used for soup-thickening. On the other hand Chemonics (2003) suggested that since amino acids are missing from a number of other sources of vegetable protein, such as soya, sesame meal or flour can be added to recipes to give a better nutritional balance to health food products. Iwo and Idowu (2007) in Mshelia (2012) also found out that sesame has great values in making candies, cakes, beverages and soap which are hawked by children to serves as a source of income to the farmers' families. Chemonics (2003) also added that the leaves may be eaten in stews while the dried stems may be burnt as fuel with the ash used for local soap making.

It is however, reported that farmers are yet to take advantage of the obvious and robust potentials of sesame. This is evidenced by the report of Falusi (2008) which ascertained that the status of sesame production in Nigeria is relatively low. OLAM (2005) also noted the poor sesame yield and attributed this to low and unstable yield potential of the available production technology, increase in the cost of input such as inorganic fertilizers, lack of technical and extension support, a complex of distinctive agricultural policies, and non- adoption of improved technology for sesame production. The problem of lack of technical and extension support services as identified by OIAM (2005) implies sesame farmers' lack of appropriate information on the right approach to improving the production.

Information as posited by Camble (1992) is germane to man's ability to manipulate factors of production such as land, labor and capital resources into meaningful and productive use. Adedoyin (1990) noted that a steady information flow of accurate, understandable and factual information links the scientist with farmers, in which for any true agricultural progress, farmers must know, understand, and act upon. Suffice this to say that how far people progress in whatever endeavor depends upon the availability and access to accurate and reliable information (Ajayi et.al 2010). Also important is information needs identification which Ajayi et.al (2010) captured as the first step in the development of any information package. Perhaps this understanding made Moris and Stilwell (2003) to suggest that farmers are always in the best position to determine whether any information is of great value to meet their needs or not. This is in view of the fact that no one can claim to know all the information needs of farmers especially in an information dependent sector like agriculture where there are arrays of new or rather complex problems facing farmers every day.

\section{Methodology}

The study was carried out in Katsina state. Katsina State is located in the North-Western region of Nigeria. The state, covers an area of $23,938 \mathrm{sq}$. $\mathrm{km}$ and is located between latitudes $11 \hat{\mathrm{A}}^{\circ} 08^{\prime} \mathrm{N}$ and $13 \hat{\mathrm{A}}^{\circ} 22^{\prime} \mathrm{N}$ and longitudes $6 \hat{\mathrm{A}}^{\circ} 52^{\prime} \mathrm{E}$ and $9 \hat{A}^{\circ} 20^{\prime} E$. The state is bounded by Niger Republic to the north, by Jigawa and Kano States to the east, by Kaduna State to the South and by Zamfara State to the West. Katsina State has rich cultural values with annual rainfall ranging from $800 \mathrm{~m}$ to $1000 \mathrm{~mm}$.

Katsina has 3 agricultural zones. The zones and the LGAs covered included:

1. Ajiwa Zone: comprises of Kaita, Jibia, Batagarawa, Rimi, Charanchi, Bindawa, Mani, Daura, Maiadua, Sandamu, Baure, Zango, Mashi, Dutsi and Katsina. 
2. Funtua zone: comprises of Funtua, Kankara, Faskari, Bakori, Dandume, Malumfashi, Kafur, Danja, Musawa and Matazu

3. Dutsin ma zone: comprises of Dutsin ma, Danmusa, Kurfi, Safana, Kankia, Ingawa, Kusada and Batsari

Two zones were randomly selected from the three zones, and these were Funtua and Dutsinzones. In Funtua, Funtua and Kankara were randomly sampled, while in Dutsin ma, Batsari and Kusada were randomly sampled as well. A list of sesame farmers were obtained and proportionately, samples were drawn from each of the four LGAs sampled. In all, a total of 140 sesame farmers were sampled for the study.

To operationalize information needs of respondents, a list of possible information needs were presented to sesame farmers, from which they indicated their needs based on the level of these needs. This was measured as high (3), moderate (2) and low (1). Weighted mean for each of these information needs was obtained and used to rank respondents needs on the basis of importance. A score of information need was obtained for each of the respondent and used to categorize respondents into high information needs ( $\geq$ mean) and low information need ( $<$ mean). Constraints to accessing information on sesame production was measured as respondents indicated based on level of severity, ranging from serious $=2$, Mild $=1$, not a constraint $=0$. An index of constraint was therefore obtained and used for hypothesis testing. Access to information sources on sesame production was equally assessed based on frequency of access to such information. This was measured as respondents indicated whether these sources were always, occasionally, rarely or never accessed, with scores of 3, 2, 1 and 0 assigned. Access to information was determined as respondents' scores for each of these sources were summed up and used for hypotheses testing. Frequency counts, percentages, means and SD were the descriptive tools used in the analysis, while chi-square and Pearson Product Moment Correlation (PPMC) were used for testing the hypotheses of the study.

\section{Results and Discussions}

\subsection{Socio-economic characteristics of sesame farmers in the study area}

The finding reveals that the mean age (Table 2) was 38 years, as $32.9 \%$ and $25.7 \%$ were aged $31-40$ and $21-30$ years respectively. This result implies that most sesame farmers are within their economically active ages and are very agile. This should be able to translate to improved productivity of sesame in the area. The result is line with that of Ikwuakam, Sangotegbe and Akinbile (2013) on the age of rural dwellers of Katsina State. The study further reveals that $95.0 \%$ of respondents were males, while only $5.0 \%$ were females. This underlines the fact that sesame and other arable farming activities are mostly carried out by men in Northern country. This is unlike what operates in the southern part of the country, where women constitute a large proportion of farming households and are engaged in different activities at the different nodes of agricultural enterprise. Ekong (2003) earlier found more male household heads of active productive age in the rural areas of southwest Nigeria than females. The study further reveals that majority (89.3\%) were married, and had Quranic education (64.3\%). These findings are peculiar to northern populace as they are known to marry early, and more disposed to the Quranic education than western education. The fact that they had mainly Quranic education suggests that they may have limited access to sources of information, especially those that can be accessed through written and other ICTs sources. However, marriage should be able to offer helping hands especially in the case of innovations that may require additional labour. The study further reveals that majority (87.1\%) belonged to the Islamic faith. This finding is not unexpected as Northern Nigeria is known to be dominated by Muslim faithful. Judamat, Abu, Adekoya and Abu (2010) found a contrary situation in the South Western Nigeria where most small ruminant farmers were Muslims, married but with appreciable level of formal education.

On household size (Table 2), the study indicates that the average household size of sesame farmers is 9 members. This means that sesame farmers have enough labour inputs from family members. One would have expected this to translate into large sesame farm sizes. The result is consistent with that of Ironkwe, Asiedu, Chinaka and Ezebuiro (2008) who found household size in Abia State to be large. However, majority (94.3\%) had 1-3 ha of sesame farmland. This infers that the farmers did not make most use of the opportunities available to them in terms of large expanse of land and labour which characterize the State. Membership status of sesame farmers in social organization was also investigated and the result reveals that majority (83.6\%) do not belong to any social organization. This may make it a bit difficult for agricultural information on improved sesame production to get across to the farmers. 
Table 2: Socio-economic characteristics of sesame farmers in the study area

\begin{tabular}{|c|c|c|c|c|}
\hline Variables & $F$ & $\%$ & Mean & SD \\
\hline Age & & & 38.66 & 11.52 \\
\hline less or equal 20 & 6 & 4.3 & & \\
\hline $21-30$ & 36 & 25.7 & & \\
\hline $31-40$ & 46 & 32.9 & & \\
\hline $41-50$ & 36 & 25.7 & & \\
\hline $51-60$ & 9 & 6.4 & & \\
\hline $61-70$ & 7 & 5.0 & & \\
\hline \multicolumn{5}{|l|}{ Marital status } \\
\hline Married & 125 & 89.3 & & \\
\hline \multirow{2}{*}{\multicolumn{5}{|c|}{ Level of education }} \\
\hline & & & & \\
\hline No formal education & 4 & 2.9 & & \\
\hline Quranic education & 90 & 64.3 & & \\
\hline Primary education & 23 & 16.4 & & \\
\hline Secondary education & 20 & 14.3 & & \\
\hline \multirow{2}{*}{\multicolumn{5}{|c|}{ Religion }} \\
\hline & & & & \\
\hline Christian & 17 & 12.1 & & \\
\hline Islam & 122 & 87.1 & & \\
\hline Traditional & 1 & 0.7 & & \\
\hline Household size & & & 9.12 & 5.70 \\
\hline $1-5$ & 43 & 30.7 & & \\
\hline $6-10$ & 58 & 41.4 & & \\
\hline $11-15$ & 21 & 15.0 & & \\
\hline $16-20$ & 13 & 9.3 & & \\
\hline above 20 & 5 & 3.6 & & \\
\hline Farm size & & & 2.00 & 1.78 \\
\hline $1-3$ & 132 & 94.3 & & \\
\hline $4-6$ & 4 & 2.9 & & \\
\hline $7-9$ & 2 & 1.4 & & \\
\hline above 9 & 2 & 1.4 & & \\
\hline \multicolumn{5}{|l|}{ Sex } \\
\hline Male & 133 & 95.0 & & \\
\hline Female & 7 & 5.0 & & \\
\hline \multicolumn{5}{|c|}{ Membership of organization } \\
\hline Yes & 23 & 16.4 & & \\
\hline No & 117 & 83.6 & & \\
\hline
\end{tabular}

Source: Field survey 2015

\subsection{Access to agricultural information sources}

The study also investigated the various sources of agricultural information that are accessed by sesame farmers in Kastina State (Table 3). The result reveals that of the various sources, personal experience was always used by $81.4 \%$, followed by radio/television (28.6\%) and friends (27.9\%). The study further reveals that friends (62.1\%), radio/television (61.4\%) and opinion leaders (55.0\%) were occasionally used. This result further buttress less emphasis formal sources have placed on dissemination of sesame related information to farmers, hence farmers' reliance on experience they have built overtime and occasionally from friend and opinion leaders.

The weighted mean score reveals that the most accessed information sources for sesame production include personal experience (2.65), radio/television (2.12), friends (2.09) and opinion leaders (1.91). The use of radio/television, as ranked $2^{\text {nd }}$ further underlines the fact that radio remains an important means by which information are accessed by farmers of different categories. It can also be inferred that the study location had no problem with radio/television signal receptivity as well as the language of broadcasting. This finding agrees with Rezvanfar, Moradnezhai and Vahedi (2007) on friends, community leaders, and Yahaya (2002) on radio, as an acknowledged, cheapest and by far the most effective means of reaching rural targets with agricultural innovations. 
Table 3: Respondents access to information on sesame production

\begin{tabular}{lccccc}
\hline Sources & Never & Rarely & Occasionally & Always & Mean \\
\hline Friends & 9.3 & 0.7 & 62.1 & 27.9 & 2.09 \\
Personal experience & 4.3 & 7.9 & 6.4 & 81.4 & 2.65 \\
Radio/television & 6.4 & 3.6 & 61.4 & 28.6 & 2.12 \\
Extension agents & 27.1 & 10.7 & 50.0 & 12.1 & 1.47 \\
Association & 40.0 & 15.0 & 40.0 & 4.3 & 1.09 \\
Mosque & 17.1 & 52.1 & 20.0 & 10.7 & 1.24 \\
Church & 93.6 & 1.4 & 5.0 & 0.0 & 0.11 \\
Newspaper/newsletters & 37.9 & 25.0 & 33.6 & 3.6 & 1.03 \\
Opinion leaders & 6.4 & 17.1 & 55.0 & 21.4 & 1.91 \\
\hline
\end{tabular}

Source: Field survey 2015

The various constraints to accessing information were also identified in order of severity as shown in Table 4 . The study reveals that majority of respondents (94.3\%) rated lack of extension agents' contact as serious constraints, just like poor television network (88.6\%), lack of power supply $(77.1 \%)$ and poor radio network $(70.7 \%)$. This finding implies that, although formal sources such as extension services, television, and radio may not have been effective in the dissemination of sesame related information, farmers still perceive them as good sources of information. Therefore, their inability to access these sources for information was considered serious constraints. It further revealed that $40.0 \%$ considered illiteracy as not a constraint and literacy as much of importance in accessing agricultural information. This may be because information sources as radio, television and extension sources most times provide agricultural information in local languages. The result corroborates that of Ozowa (1995) who observed that the apparent constraints in agricultural information dissemination and access in Nigeria include those of inadequate extension agents, poor reception quality and covered and improper airing time which does not get to the targeted audience

Table 4: Constraints to accessing information on sesame production

\begin{tabular}{lcccc}
\hline Constraints & Not a constraint & Mild & Serious constraint & Mean \\
\hline Lack of extension agents contact & 2.1 & 3.6 & 94.3 & 1.92 \\
Illiteracy & 40.0 & 33.6 & 26.4 & 0.86 \\
Lack of power supply & 5.0 & 17.9 & 77.1 & 1.72 \\
Lack of modern information operational skill & 5.7 & 30.0 & 64.3 & 1.59 \\
Poor television communication network & 1.4 & 10.0 & 88.6 & 1.87 \\
Poor radio communication network & 9.3 & 20.0 & 70.7 & 1.61 \\
Lack of agriculture based television programme & 0.7 & 30.7 & 68.6 & 1.68 \\
Lack of agriculture based radio programme & 12.9 & 37.1 & 50.0 & 1.37 \\
\hline
\end{tabular}

Source: Field survey 2015

\subsection{Information needs of sesame farmers}

Table 5 presents the information needs of sesame farmers in Kastina state. The study reveals that respondents rated their needs of use of fertilizer/manure (77.9\%), pest and disease management practices as high (74.3\%), just like agricultural insurance $(72.9 \%)$, agricultural credit facilities (72.1\%). This revelation suggests that respondents are being faced with challenges that bother on improved productivity, access to financial capital as well as risk management ability. The study further revealed that farmers' information needs for improved sesame seeds ranked first (2.77), followed by better storage devices (2.68), agricultural insurance (2.67) and pest and disease management practices (2.66). The least ranked information needs of the farmers included weather information (2.34), new irrigation method (2.32) and modern sesame processing methods (2.46). This finding suggests that the climatic condition of the area irrespective of the recent seasonal variation, occasioned by climate change has not posed any significant threat to sesame production. Also, there appears to be some level of satisfaction with the current processing practices in use by farmers, as $53.6 \%$ relative to other areas of needs rated this high. Okwu and Umoru (2008) identified similar areas of information needs among women farmers in Apa LGA of Benue State. 
Table 5: Information needs of sesame farmers on sesame production

\begin{tabular}{lcccc}
\hline Information needs & Low & Moderate & High & Mean \\
\hline Modern production practices & 7.1 & 20.7 & 72.1 & 2.65 \\
Improved seeds & 0.0 & 22.9 & 77.1 & 2.77 \\
Better storage devices/methods & 1.4 & 29.3 & 69.3 & 2.68 \\
Pest and disease management practices & 7.9 & 17.9 & 74.3 & 2.66 \\
Fertilizer/manure & 2.9 & 19.3 & 77.9 & 2.75 \\
Herbicides & 4.3 & 35.7 & 60.0 & 2.56 \\
New irrigation method & 14.3 & 39.3 & 46.4 & 2.32 \\
Modern processing method & 7.1 & 39.3 & 53.6 & 2.46 \\
Weather information & 13.6 & 38.6 & 47.9 & 2.34 \\
Agricultural credit facilities & 9.3 & 18.6 & 72.1 & 2.63 \\
Agricultural insurance & 5.7 & 21.4 & 72.9 & 2.67 \\
Soil and irrigation movement & 7.1 & 30.7 & 62.1 & 2.55 \\
Market channels & 5.7 & 27.1 & 67.1 & 2.61 \\
\hline
\end{tabular}

Source: Field survey 2015

A summary of the level of information needs by sesame farmers is presented in Table 6 . Respondents have been categorized into two, based on their levels of information needs for sesame production, using their overall mean information need score as the benchmark. The table reveals the maximum information needs score as 39.00 , and the minimum as 14.00 , while the mean was 33.74. Respondents with scores of 33.73 and below were therefore categorized as low while those with scores of 33.74 and above were categorized as high. The result reveals that majority were categorized to have a high level of information needs. This implies that in order to expand the scope of sesame production and impacting meaningfully on the standard of living of the people, the various needs identified will have to be met.

Table 6: Levels of information needs of sesame farmers

\begin{tabular}{ccccccc}
\hline Level of information needs & $\mathbf{F}$ & $\%$ & Mean & SD & Minimum & Maximum \\
\hline Low & 49 & 35.0 & \multirow{2}{*}{33.74} & 4.78 & 14.00 & 39.00 \\
High & 91 & 65.0 & & & & \\
\hline
\end{tabular}

Source: Field survey 2015

5.4 Relationship between respondents' socio-economic characteristics, access to information sources, constraints to accessing information and their levels of information needs

Table 7 reveals that only religion $\left(\mathbf{X}^{2}=4.833\right.$ ) showed significant relationship with respondents' level of information needs, while education $\left(X^{2}=4.833\right)$, sex $\left(X^{2}=0.134\right)$ and membership of social organization $\left(X^{2}=1.990\right)$ showed no significant relationship with their information needs. This implies that information needs of sesame farmers do not vary whatsoever across these identified educational, sex and organizational status groups. This may also be due to the fact that sources of information accessed by farmers mostly are from informal sources which do not discriminate by across groups. The finding is in tandem with that of Ajayi and Banmeke \& Solomon (2010) on oil palm farmers' information needs in Esan Central Local Government Area of Edo State, Nigeria.

Table 7: Chi-square analysis showing relationship between respondents' socio-economic characteristics and their levels of information needs

\begin{tabular}{lccccc}
\hline Variable & $\mathbf{X}^{2}$-value & Df & P & CC & Decision \\
\hline Level of education & 4.833 & 4 & 0.305 & 0.183 & NS \\
Religion & 7.928 & 2 & 0.019 & 0.232 & S \\
Sex & 0.134 & 1 & 0.714 & 0.031 & NS \\
Membership of organization & 1.990 & 1 & 0.158 & 0.118 & NS \\
\hline
\end{tabular}




\subsection{Relationship between respondents' socio-economic characteristics and their levels of information needs}

Table 8 also reveals that only farm size $(r=0.17)$ had significant relationship with farmers' level of information needs, revealing that farmers with large farm sizes needed more information compared to others with smaller farm sizes. This may be connected to the risk involved in operating large farms. Also, since farmers with large farms exhibit more levels of commitment as a result of high investment in sesame production, they tend to value information than farmers with smaller farm sizes in the area. However, no significant relationship existed between respondents' household size, access to information sources and respondents level of information needs. This implies that the various information sources to which farmers have access did not significantly correlate with their information needs. No significant relationship was also found between respondents' level of constraints to accessing information and their levels of information needs in the study area.

Table 9: Relationship between respondents' socio-economic characteristics and their levels of information needs

\begin{tabular}{lccc}
\hline Variable & $\mathbf{r}$-value & $\mathbf{P}$ & Decision \\
\hline Age & -0.026 & 0.762 & $\mathrm{NS}$ \\
Household size & 0.025 & 0.969 & $\mathrm{NS}$ \\
Farm size & 0.178 & 0.036 & $\mathrm{~S}$ \\
Access to information & 0.139 & 0.101 & $\mathrm{NS}$ \\
Constraints & -0.048 & 0.221 & $\mathrm{NS}$ \\
\hline
\end{tabular}

\section{Conclusion and Recommendations}

The study shows that the respondents are young with large family size that requires appropriate information provision to expand their small scale sesame production. Personal experience, radio/television and friends were major sources the respondents accessed relevant information. Access to information by majority was constrained by lack of extension agents' contacts, poor television communication network and lack of power of power supply. Majority had high level of information needs with fertilizer/manure, pest/diseases management practices, agricultural insurance and credit as major areas of information needs. Farm size and religion were significantly related with sesame farmers' level of information needs. Based on the findings, the following recommendations are made:

1. There is the need for extension programme to be revitalized in Katsina State with the aim of addressing the common needs of farmers on economically important crops such as sesame.

2. There is urgent need for the state government to pay attention to rural power infrastructure and provision as well as address the poor rural telecommunication signals that has prevented rural dwellers from enjoying regular television programs

\section{References}

Abdullah, N.M. (2009). Nigeria Sesame seeds farming can provide 1 million jobs $\$ 1.5$ Bil for northern states

Abu, G.A., P.I. Ater and D. Abah (2012). Profit Efficiency among Sesame Farmers in Nasarawa State, Nigeria Current Research Journal of Social Sciences 4(4): 261-268

Adedoyin S.T (1990). Linkage in the Development and Delivery of Agricultural Research Information by Nigeria Research Institutes, Unpublished Ph.D. Thesis in the Department of Communication and Language Arts, University of Ibadan, Nigeria: pp. 69-71

Aina, L.O (2004). Library and Information Services to the Neglected Majority in Africa: The Need for a Restructuring of LIS Curriculum in Africa, In: Towards a knowledge Society for African Development. Proceeding of $16^{\text {th }}$ Standing Conference of Eastern, Central and Southern African Librarians, Kampala: Uganda Library

Aina, L.O., Kaniki, A.M., and Ojiambo, J.B. (1995). Preface.inAina, L.O., Kaniki, A.M., and Ojiambo, J.B. (Eds), Agricultural information in Africa. Ibadan: Third World Information Services

Ajayi, M.T., T.O.A. Banmeke and O. Solomon (2010). Information needs of Oil palm Farmers in Esan Central Local Government Area of Edo State, Nigeria in Nigerian Journa of Rural Extension and Development. Vol. 3

Anon, O (2008).World Sesame Situation: American Sesame Growers' Association. http//www.worldstatuofsesame.mht. Accessed on $24 / 8 / 2009$.

Burden, D. (2005).Sesame Profile.http//www.cropprofile.mht.Accessed on 26/8/2009.

Cample, E (1992) Access to and Utilization of Quality information in Rural Development Programme in Buma Zone of Borno State Unpublished Ph.D. Thesis, Department of Liberary, Archival and Information Studies, University of Ibadan, p.119

Chemonics (2003) Overview of the Nigerian Sesame Industry. Washington DC: Chemonics International Inc. 
Ekong, E. E (2003). An introduction to rural sociology.Uyo;Dove Education Publishers, Pp. 341-371

Falusi, O.A. (2008). A survey of sesame (Sesame indicum L.) production and use in Nigeria. Available on-line at http://d.wanfangdata. com.cn/NSTLQK NSTL QK19134422.aspx

FAO (2008): Key Statistics of food and agriculture external trade. FAOSTAT Database. Available on-line at <http://www.fao.org/es/ess/ toptrade/trade.asp./accessed 03/09/2015

Food and Agricultural organization (2000): FAOSTAT. Database. Available at <http:/apps.fao.org/default.htm>./accessed 03/09/2015

Food and Agricultural organization of the United Nations (2009). FAOSTAT Database. Available on-line at <http:/apps.fao.org/default. $h \mathrm{tm}>$.

Ikwuakam, O. T., N. S. Sangotegbe and Akinbile (2013). Perceived Nutritional And Medicinal Values of Moringa oleifera (Zogale) Among Rural Dwellers of Katsina State, Nigeria. Nigerian Journal of Rural Sociology,14(1): 49-59

Judamat, Z. A., A.E. Adekoya and O.A. Abu (2010). Information needs of Small Ruminant Rearrerss in Peri-Urban Areas of SouthWest Nigeria in African Journal of Livestock Extension

Morris, C.D and Stilwell, C. (2003).Getting the Write message write; Review of guidelines for producing readable print agricultural information materials. South African Journal of Libraries and Information Science Vol. 69 No.1 pp.71-83

Mshelia, J. S, A. A. Sajo and D.T. Gungula (2012). Sesame Production as Panacea for Poverty Alleviation in Nigeria Journal of Agriculture and Veterinary Sciences Volume 4, June

Nasarawa State Government, (2008).Ministry of Information.Lafia Annual Report

Okwu, O.J and Umoru B.I (2008) A Study of Women Farmers' Agricultural Information Needs and Accessibility: A Case of Apa LGA of Benue State, Nigeria. Proceeding of the first national conference of the Society for Gender in Agriculture and Rural Development. Pp202

OLAM, (2005).Improved Package of Practices for Sesame Production Out-Grower (Training Manual). Lagos: OLAM Nigeria Limited.

Olowe, V.I.O; Y.A. Adeyemo and O.O. Adeniregun (2009). Sesame; the under exploited Sesame Production as Panacea for Poverty Alleviation in Nigeria organic oilseed crop. Available on-line at www.unep-unctad.org/.../23sesame\%20the\%20underexploited \%20organic\%20oil\%20seed\%20crop\%20paper\%201pdflaccessed 5/09/2015

Ozowa, V.N (2004). Information Needs of Small Scale Farmers in Africa: The Nigerian Example. The Quarterly Bulletin of the International Association of Agricultural Information Specialists, IAALD/CABI, 40 (1)

Purseglove, J.W., (1996). Tropical Crops Dicotyledons. Longman, London, 1: 435.

Raw Materials Research and Development Council (RMRDC) (2004).Report on Survey of Agro-Raw materials in Nigeria: Beniseed (1st ed). Abuja: Raw materials Research and Development council Garki.

Rezvanfar, A., H Moradnezhai and M Vahedi (2007). Information needs of farm women related to dairy farming and home management in Ilam State of Iran. Livestock research for Rural Development 19(8)

Umar, H.S, Okoye, C.U and Mamman, B.D (2010). Resource use efficiency in sesame (sesamum indicum I.) Production under organic and inorganic fertilizers applications in keana local government area of nasarawa state, Nigeria. Journal of Environmental Issues and Agriculture in Developing Countries 2 (1), 207-218

USAID (2002). Overview of the Nigerian Sesame Industry Nigeria: United States Agency for International Development (USAID)

Yahaya, M. K. (2002). Gender and communication variables in agricultural information dissemination in two agro-ecological zones of Nigeria, Ibadan, Nigeria: Corporate Graphics 